India and at Elvaston Place, will never be forgotten by the many friends who were privileged to enjoy it.

Mr. Brandreth leaves an only child, a daughter, now the wife of Mr. J. G. Butcher, K.C., late M.P. for York.

January, 1908.

T. H. T.

\title{
MAJOR-GENERAL SIR FREDERIC JOHN GOLDSMID, K.C.S.I., C.B.
}

THE death of Mr. E. L. Brandreth at the ripe age of 84 has been quickly followed by the death of another Honorary Vice-President, the distinguished officer above named, who passed away on the 12th January at the still riper age of 89 .

The deceased was a good specimen of a class to which the world in general, and India and the East particularly, are much indebted - a class of which our late Director, Sir Henry Rawlinson, was a fine example-the Military Civilian ; combining indomitable energy, mental as well as physical, quickness of perception, accuracy of work and statement, together with the military instinct of respect for orders and instructions.

The subject of this memoir had all these virtues and many more. Besides being a good soldier he was a remarkable linguist. Having lived in France and Italy when young, he spoke French equally well with English and Italian with facility; at college he distinguished himself in classics, and made himself, as time went on, master, in more than a colloquial sense, of Persian, Arabic, and Turkish, in addition to Ūrdū, Sindi, and other Indian vernaculars. In Sind he proved himself a good Magistrate and Judge, with a keen interest in education, and a careful investigator of complicated questions of tenure 
and the like; in political work he was tactful as well as energetic; and in later years he was a good director of the work of others-a chief under whom it was a pleasure to serve, for he always gave subordinates full credit for good work, minimising his own performances, and stimulating by example rather than by criticism; a good writer - at times, perhaps, voluminous, but always clear and forcible, and in describing scenery and journeyings particularly bright and interesting; a valued contributor to reviews and the Encyclopædia; and author, inter alia, of "Telegraph and Travel," "Eastern Persia," and, above all, of the "Life of Outram." In character a man of singular modesty; "a fine soldier and administrator," says one of his biographers, "with the heart of a little child"; of deep religious feeling, without a trace of bigotry; a most genial companion and, to his friends, one of the most lovable of men.

Sir Frederic was born at Milan in 1818, the only son of Mr. Lionel Prager Goldsmid, an officer of the 19th Dragoons. On his father's side he was of Jewish descent, the scion of a well-known City family, but through his grandmother, Mrs. Benjamin Goldsmid, his branch of the family became Christian, and Sir Frederick himself was through life a member of the Church of England.

He was educated partly at an English school in Paris, partly at King's College School, and King's College, London. He was destined for a military career, and in January, 1839, entered the Madras Army, joining his regiment, the 37th Madras N.I., in the April following.

Of his subsequent career as soldier, administrator, diplomatist, and writer, a brief but good account is given in the Times of January 13th, and those who would know more of his religious life and work after retirement and the "beauty and simplicity and unselfishness" of his personal character should read the obituary notice in the Church Times of the 24th. 
The year during which young Goldsmid joined the Army was the year of the first Afghān war. He did not take part in that campaign, but in August of the following year his regiment was ordered to proceed to China, and he there took part in the actions at Canton and along the coast, which preceded the treaty of Nankin -receiving the Chinese war medal. While the campaign was in progress he was appointed Adjutant of his regiment; it was then that he turned his attention to the study of Eastern languages, in which he became afterwards so remarkably proficient, and in 1845 he qualified as interpreter in Hindūstāni.

In 1846 he had to return to England on medical certificate, but did not lead an idle life, acting during the two years of his residence in England as orderly officer at Addiscombe. In 1848 he returned to India, and, continuing his studies, passed the qualifying examinations, and was appointed in 1849 Interpreter for Persian and in 1851 for Arabic. In the same year, having obtained his company, he was appointed to act as Assistant-Adjutant-General of the Nagpur Subsidiary Force. It was at this juncture that, through the influence of the great General John Jacob, he entered Civil employ in the recently acquired province of Sind, first as Deputy Collector and then as Assistant Commissioner for Special Enquiry into "the Settlement of Alienated Lands." $\mathrm{He}$ quickly mastered Sindi, passing the examination for Interpreter, and was recognized as a very promising officer.

In 1855 he had again to proceed to England on medical certificate, but, his health being recruited by the voyage, he at once volunteered for active service in the Crimea, and was forthwith attached to the Turkish Contingent as Assistant-Adjutant-General under General Vivian; here he acquired Turkish, was made President of the Local Examining Committee at Kertch, and, in 
recognition of his services, received the Turkish war medal, the order of the fourth class Medjidieh, and the brevèt rank of Major in the Army.

In 1856 he returned to India and was appointed to the post of Judge at Shikārpur, subsequently resuming his enquiry into the "Alienated Lands," and soon afterwards he was attached to the staff of Sir Bartle Frere, who had succeeded to the office of Commissioner in Sind, and at once appreciated Major Goldsmid's ability and character.

In this capacity he showed much tact and energy, did good service during the anxious period of the great Mutiny, and was subsequently employed on more than one Special Commission. In 1861 he was deputed to arrange with the Chiefs in Balūchistān and Makrān for the construction of a land-line of telegraph along the coast to Gwädar, and received the thanks of the Bombay Government for the "speedy and successful issue of his negotiations."

In 1862 he again went to England on sick-leave, ${ }^{1}$ returning to India in November, 1863, with the rank of Brevet Lieutenant-Colonel. About this time it was decided to establish overland telegraphic communication from Europe through Persia and Balūchistān to India, and Colonel Goldsmid was at once selected to take part in the undertaking. Accordingly in 1864 he accompanied the late Colonel Patrick Stewart, R.E., when laying the cable in the Persian Gulf; later on he proceeded overland to Constantinople vid Turkish Arabia and Asia Minor-a long and arduous journey-and after much reporting and discussion had the satisfaction of conveying

1 On this occasion the writer of this memoir had the pleasure of accompanying him for part of the journey, and well remembers how greatly he enjoyed Major Goldsmid's conversation, and how much he was struck by his classical knowledge as well as his perfect mastery of Arabic and Persian. 
the Indo-Ottoman Telegraph Treaty duly signed to England. In the beginning of 1865, on the death of Colonel Stewart, he was appointed Director-General of the Indo-European Telegraph, and proceeded at once, viâ Russia and the Caspian, to Tehrān, to assist Her Majesty's Minister in negotiating a Telegraph Treaty with the Persian Government. Having obtained the required convention he started overland for India, and, after a trying journey of $2 \frac{1}{2}$ months through the then little-explored tracts of Eastern Persia and Balūchistān, reached Chārbār, a port of Makrān in 1866; thence going forward to Simla to report the proceedings to the Viceroy. He then started again for Europe, submitted the draft of a supplemental Convention to the India Office, and the same year returned to the Persian capital with a view to further negotiations. For these services he received the thanks of the Government of India; all his proposals were approved, and the Companionship of the Bath was conferred upon him.

After being delayed at Tehrān by a temporary hitch he proceeded to India to confer with the Governor of Bombay, and thence again to England, where the difficulty was finally settled. As a measure of the mere physical toil involved in these operations-irrespective of worries, anxieties, and hardships-it was computed by the late Sir Henry Yule that Colonel Goldsmid's land-journeys alone must have covered a distance of at least 5,700 miles.

But this was not all; on his return journey from England to India he was engaged in somewhat protracted negotiations with the French authorities on the terms of admission of the Indo-European Telegraph into the general system of telegraphs in Europe. These were satisfactorily settled.

In 1868 Colonel Goldsmid attended the Telegraph Conference in Vienna, where he was received with great honour by the Emperor and his Ministers as the 
accomplisher of a great work, and thereafter proceeded to Bombay to resume the work of telegraph extension to the West. In 1869, in furtherance of this object, he again visited Makrān, Gwādar, and Chārbār, and provided for the better security of the cable by transferring it from the Arabian shore of the Persian Gulf at Rás Masandom to the island of Henjām just off the Persian shore. The Indo-European Telegraph having been now fairly organized, Colonel Goldsmid resigned the directorship in 1870 in favour of the Assistant Chief Director, Major (the late Colonel Sir John) Bateman Champain, R.E.

During the six years of his work as Director-General he had not only helped to fix the alignment of the telegraph and make arrangements with the Turkish and Persian Governments for its protection, as described in the preceding paragraphs, but he personally superintended the erection of the poles and the carrying of the wires across the whole extent of the Shah's dominions. Of that arduous work he gave an interesting and modest account in his volume entitled "Telegraph and Travel" (published in 1874), rendering full justice to the efforts of his assistants, and saying little or nothing of his own; showing at the same time such great powers of description that his narrative was pronounced by the Press to be "as interesting as it was important."

But new work was soon found for Colonel Goldsmid. It had long been known that the boundary between Persia and Balūchistan sorely needed delimitation, and the necessity was all the greater now that an important telegraph-line passed through the territories of both; it was decided, therefore, in 1871, to appoint Colonel Goldsmid a Commissioner to arrange for such delimitation, with the local rank of Major-General and a suitable staff. The task was a difficult and delicate one, but the boundary proposed by the British Commissioner was at last accepted by the Persian Government, and on the return of the 
Commission to England Major-General Goldsmid was made a Knight Commander of the Star of India, and received "the warm acknowledgments of the Viceroy and Governor-General of India in Council."

In the same year Sir Frederic was entrusted with a far more difficult task, that of defining the boundary between Persia and Afghänistān in the disputed province of Sistān. A full account of his proceedings and the text of his arbitral award is contained in a voluminous collection of papers relating to Eastern Persia, including reports by members of his staff, ${ }^{1}$ edited by Sir Frederic, with an introduction by himself, and published under the direction of the Government of India in 1876.

Suffice it here to say that, after careful historical research, much surveying and investigation on the ground, and great difficulties caused by the Persian Commissioners and the attitude of the representative of the Amir of Käbul (Sher Ali Khan), who was accompanied by Colonel (afterwards Sir Richard) Pollock representing the Viceroy of India, the arbitral award was declared at Tehrān on August 19th, 1872.

It failed to satisfy either party. This is no matter for surprise; and is testimony to the arbitrator's impartiality. He was required by his instructions to "pay special regard to ancient right and present possession "; but the questions involved were complex, and as the parties were keenly hostile it was impossible to give a decision acceptable to both. The award was confirmed by Her Majesty's Government after considering the objections of the parties, and the thanks of the Government of India were given to Sir Frederic Goldsmid " for the tact and good judgment

1 Viz., Major Oliver (afterwards Sir (Oliver) St. John, R.E. ; Major Beresford Lovett, R.E. (afterwards Major-General, C.B., C.S.I.) ; Major Euan Smith (afterwards Colonel Sir Euan Smith, K.C.B., C.S.I.); W. T. Blanford, C.I.E., F.R.S. 
he had displayed through these negotiations under circumstances of no ordinary difficulty." It should be added that though the award satisfied neither party, it had the highly beneficial effect of maintaining peace.

With the arbitration award Sir Frederic's career in India terminated. On the 1st January, 1875, after 35 years of arduous service, Sir F. Goldsmid retired from the Government service with a special pension and the rank of Major-General.

But Sir Frederic was not destined to lead an idle life. $\mathrm{He}$ at once devoted himself to the preparation of the voluminous Report on Eastern Persia, which has already been referred to, and was further entrusted with an important work for which he was well fitted both by knowledge and by sympathy-the biography of General Sir James Outram, "the Bayard of India." The work was completed in two volumes in $\mathbf{1 8 8 0}$ and was a literary success.

But though Sir Frederic had retired from Government service he was still considered more or less indispensable, and was appointed in 1877 British Representative of an International Commission to enquire into the matter of coolie emigration to the Island of $\mathrm{La}$ Réunion. In company with a French Commissioner he proceeded to the island and made a tour of the estates, and a joint report was issued in February, 1878, and a separate report in the April following. For this enquiry he received the acknowledgments of the Government of India, and in this the Secretary of State "entirely concurred." On June 14th of the latter year he delivered a lecture at the Royal United Service Institution on "Communications with India under possible contingencies," an elaborate paper for which he was cordially thanked by Colonel (afterwards Sir Henry) Yule, R.E., who presided.

In 1880 Sir Frederic accepted the office of British Controller of the Daira Sanieh (Crown lands) in Egypt, 
and was there during the outbreak in September, 1881. In June, 1882, he was sent for by Lord Granville and despatched on a mission to Constantinople, and on returning thence to Alexandria he organized an Intelligence Department, which rendered useful service until the surrender of Arabi after the victory of Tel-el-Kebir. For these services he received the thanks of the Commanderin-Chief in Egypt (Viscount Wolseley) and the War Office. On the 1st of May, 1883, he resigned his office of Controller of Egyptian Crown lands, and received from the Khedive the Osmanieh Decoration of the second class and the Bronze Star.

Leaving Egypt he accepted an invitation from the King of the Belgians to proceed to the Congo as "Administrateur Délégué" with a view of carrying out special measures for the organization of the new state. He landed at Banana Point on September 4th, 1883, and proceeded with his staff up country. Had he been able to remain and properly organize the administrative system, much good may have resulted, but he was soon prostrated by severe illness, and had, to his great disappointment, to return to England from Loanda, reaching London on the 31 st of December.

This may be termed Sir Frederic's last appearance in a public capacity, and during the remaining years of his life he devoted his attention partly to literary work, consisting of contributions to newspapers, reviews, and works of reference, like the "Encyclopædia Britannica," a sphere in which he gained the reputation of being a laborious and conscientious writer; and he also wrote an interesting preface to a new edition of Morier's Hājī Bābā. Besides his literary work he took an active interest in various philanthropic and religious institutions. For many years he was an interested member of the Committee of the Gordon Boys' Home (which he helped to found), also of the Committee of the S.P.G., and was of the 
greatest assistance to Archbishop Benson in founding his Mission to the Assyrian Christians.

Sir Frederic's connection with the Royal Asiatic Society commenced in 1864, the year after he had published a metrical translation of the Sindi legendary poem of Susswi and Punh $\bar{u}$, and in 1865 he furnished a paper on the "Preservation of National Literature in the East," suggested by his interest in folklore, a paper in which he advocates the introduction into Sind of an official language and character (then non-existent) with a view not only to public convenience, but to prevent the legendary poems and oral traditions of the country dying out. The proposed measure was adopted, and the official language and character are now known as Arabic-Sindī.

He was an ordinary member of the Council for brief periods between 1875 and 1889 ; and between November, 1885, and June 30th, 1887, he held the post of Secretary, a post which, to the great regret of the Council, he was constrained to resign, but not before he had improved the Journal by the introduction of the "Notes of the Quarter" which are now included in it. He was a VicePresident from 1890 to 1905 , and on his retirement from increasing infirmities was appointed Honorary VicePresident.

He was also a Vice-President of the Royal Geographical Society, and presided at the Geographical Section of the British Association Meeting of 1888.

On the principle that a man is known from his "companions and his recreations" it may be mentioned, in conclusion, that among his great personal friends in England were, in early years, Thackeray, Balfe, Charles Kean, and various artists, and in later years Archbishop Benson, besides his fellow-workers in India, Sir Bartle Frere, Sir Henry Green, Sir Bateman Champain, R.E., and many others with whom he remained on terms of cordial intimacy; and that latterly his favourite recreations were 
four-Eastern politics, Literature, hearing good Music, and the Drama. Age and deafness interfered with these enjoyments, but did not affect his cheeriness or interest in mundane affairs. As to his manner of life it was simple and methodical; he was fond of early rising, took regular exercise, but was not a golfer, cared not for cards or billiards, was not an abstainer, but 'moderate' in all things. He kept up his classics to the last, and in his 90th year addressed a postcard in Greek to one of his grandsons.

He was buried at Hollingburne, in Kent, where he once lived for many years, and among the multitude of tributes sent was a wreath from the R.A.S., a meeting of which he had attended not many months before his death.

Sir F. Goldsmid married in 1849 Mary, eldest daughter of Lieut.-General Mackenzie Steuart; she died in 1900. He leaves two sons and four daughters: one of the former is a retired officer of the Bengal Staff Corps; one of the latter has proceeded to India, and seems to have inherited her father's facility for acquiring Eastern languages.

February, 1908.

T. H. T.

\section{ROBERT A'TKINSON, LL.D., D.LITT.}

May an old pupil dedicate a few lines to the memory of one to whom he owes more than he can tell, and whose friendship he has been proud to retain unbroken for nearly 40 years. Professor Atkinson was not himself a member of the Royal Asiatic Society, but more than one of those who have taken an active part in the work of its Council are indebted to him for their early training, and a long list of his pupils could be compiled 